\section{Assessing the Effectiveness of V-BID Implementations}

We were delighted to read 2 thoughtful perspectives addressing the effectiveness and limitations of value-based insurance design (V-BID) in the July issue of JMCP. ${ }^{1,2}$ Implemented by numerous private and public payers, including Medicare, TRICARE, and several state employee plans, V-BID is one of the few health care reform initiatives with bipartisan political and broad multistakeholder support. The authors recognize the significant potential of aligning consumer cost sharing with the clinical value of medical services. They also acknowledge the modest adherence effect of V-BID programs that lower outof-pocket drug costs, as well as the lack of data demonstrating improved patient-centered outcomes or aggregate cost savings following most V-BID implementations. These shortcomings aside, the evolution of V-BID in prescription drugs and other clinical services demonstrates that it is feasible to increase accessibility to evidence-based services and lower medical expenditures, especially when coupled with efforts to reduce spending on low-value care.

As noted by Yeung (2019), ${ }^{2}$ the most significant and successful implementation of V-BID is Section 2713 of the Affordable Care Act (ACA), which eliminates consumer cost sharing for specified preventive services as determined by the United States Preventative Services Task Force (USPSTF) and the Centers for Disease Control and Prevention. ${ }^{3}$ The U.S. government estimates that over 130 million Americans have improved access to a number of preventive services with zero cost sharing. ${ }^{4}$ The removal of out-of-pocket costs for evidencebased screenings, counseling, and immunizations is one of the ACA's most popular specifications. ${ }^{5}$ Although prescription drug classes are rarely designated by Section 2713, this V-BIDinformed ACA provision affects managed care pharmacy. Notable examples include oral contraceptive therapy, which results in approximately $\$ 1.4$ billion in annual patient savings, ${ }^{6}$ and pre-exposure prophylaxis (PrEP) to reduce incidence of human immunodeficiency virus (HIV) infections in high-risk individuals. ${ }^{7}$ In June 2019, the USPSTF provided PrEP an A rating, which under Section 2713, requires managed care plans to provide first dollar coverage, a policy that public health experts believe will significantly increase uptake and reduce HIV disease burden. ${ }^{8}$ The more substantial and indirect pharmacy effects of Section 2713 result from enhanced use of screening tests for conditions such as hyperlipidemia, diabetes, depression, hepatitis $C$ virus, and several cancers, the treatment of which have important implications on drug spend.

Financial barriers to high-value care, including the welldocumented increase in plan deductibles, are particularly significant for low-income individuals and families, as well as those with chronic conditions. On July 17, 2019, pursuant to President Trump's Executive Order 13877 and the bipartisan, bicameral Chronic Disease Management Act of 2019 (S. 1948 and H.R. 3709), ${ }^{9-11}$ the U.S. Department of the Treasury released Notice 2019-45.12 This guidance allows health savings account-eligible high-deductible health plans (HSA-HDHP) the flexibility to cover specific services for chronic disease management before meeting a plan deductible. Effective immediately, HSA-HDHPs can cover specified chronic disease medications and services, providing a health plan option that better fits the clinical and financial needs of many Americans with chronic conditions.

Because cost-sharing increases impose a greater burden for the poor, it is important to note the potential role of V-BID in reducing health care disparities. In a follow-up study of the MI-FREEE trial referenced by Farley (2019), ${ }^{1}$ a V-BID implementation targeting individuals with cardiovascular disease was found to significantly reduce racial disparities in medication adherence, clinical outcomes, and total health care expenditures. ${ }^{13}$ These findings influenced the 2019 decision by the Center for Medicare and Medicaid Innovation to allow Medicare Advantage (MA) plans to set cost sharing based on enrollee socioeconomic status for the first time in the nationwide MA V-BID Model Test. ${ }^{14}$

A robust body of evidence supports that V-BID programs that reduced cost sharing modestly increased uptake of highvalue services. ${ }^{15}$ However, achieving aggregate cost savings is challenging, necessitating equal attention to the identification, measurement, and removal of low-value care-services that do not provide clinical benefit. ${ }^{16}$ While most of the V-BID interventions discussed in the JMCP perspectives focused exclusively on decreasing cost sharing for high-value drugs, next generation V-BID programs also increase cost sharing for low-value services in order to pay for the increased use of essential care. A plan prototype for the individual insurance marketplace, V-BID X, has recently been introduced that identifies specific high- and low-value services and bases cost sharing for those services on clinical value. ${ }^{17} \mathrm{~V}$-BID X uses actuarial modeling to vary cost sharing for targeted services to keep total spending cost-neutral, enabling enhanced access to high-value care without increasing premiums and/or deductibles. ${ }^{17}$

V-BID programs demonstrate that it is possible to improve accessibility to drugs and other medical services determined to improve patient-centered outcomes without increasing total health care costs. By abandoning blunt cost-sharing strategies and using a more clinically nuanced approach, V-BID plans incentivize consumers to use more care that improves their health and less care that does not. In recognizing that not all health care services produce that same amount of benefit to patients, V-BID implementations, despite their imperfections, are more likely to better meet the financial and medical needs of managed care beneficiaries than less clinically driven designs. 


\section{Beth Shrosbree, BS}

Research Associate

Center for Value-Based Insurance Design

University of Michigan, Ann Arbor

shrosbet@umich.edu

\author{
A. Mark Fendrick, MD \\ Director \\ Center for Value-Based Insurance Design \\ University of Michigan, Ann Arbor \\ amfen@umich.edu
}

\section{DISCLOSURES}

No outside funding supported the writing of this letter. Fendrick discloses consulting relationships with AbbVie, Amgen, Centivo, Community Oncology Association, Department of Defense, EmblemHealth, Exact Sciences, Freedman Health, Health at Scale Technologies, Health Management Associates, Lilly, MedZed, Penguin Pay, Risalto, Sempre Health, State of Minnesota, Wellth, and Zansors and also discloses a research relationship with AHRQ, Boehringer-Ingelheim, Gary and Mary West Health Policy Center, Laura \& John Arnold Foundation, National Pharmaceutical Council, PCORI, PhRMA, RWJ Foundation, and State of Michigan/CMS. Shrosbree has nothing to disclose.

\section{REFERENCES}

1. Farley JF. Are the benefits of value-based insurance design conclusive? J Manag Care Spec Pharm. 2019;25(7):736-38. Available at: https://www.jmcp. org/doi/full/10.18553/jmcp.2019.25.7.736.

2. Yeung K. Value-based insurance design: current evidence and future directions. J Manag Care Spec Pharm. 2019;25(7):738-41. Available at: https:// www.jmcp.org/doi/full/10.18553/jmcp.2019.25.7.738.

3. HealthCare.gov. Preventive health services. Available at: https://www. healthcare.gov/coverage/preventive-care-benefits/. Accessed August 5, 2019.

4. Office of the Assistant Secretary for Planning and Evaluation. The Affordable Care Act is improving access to preventive services for millions of Americans. May 14, 2015. Available at: www.aspe.hhs.gov/pdf-report/affordable-care-act-improving-access-preventive-services-millions-americans. Accessed August 10, 2019

5. Henry J. Kaiser Family Foundation. Kaiser Health Tracking Poll: November 2016. December 1, 2016. Available at: https:/www.kff.org/healthcosts/poll-finding/kaiser-health-tracking-poll-november-2016/. Accessed August 5, 2019

6. Henry J. Kaiser Family Foundation. The future of contraceptive coverage. January 9, 2017. Available at: https://www.kff.org/womens-health-policy/ issue-brief/the-future-of-contraceptive-coverage/. Accessed August 5, 2019.
7. U.S. Preventive Services Task Force. Preexposure prophylaxis for the prevention of HIV infection: U.S. Preventive Services Task Force recommendation statement. JAMA. 2019;321(22):2203-13. Available at: https://jamanetwork.com/journals/jama/fullarticle/2735509. Accessed August 5, 2019.

8. Walensky RP, Paltiel AD. New USPSTF guidelines for HIV screening and preexposure prophylaxis (PrEP): straight A's. JAMA Netw Open. 2019;2(6):e195042. Available at: https://jamanetwork.com/journals/jamanetworkopen/fullarticle/2735689. Accessed August 5, 2019.

9. Improving price and quality transparency in American healthcare to put patients first. Executive order 13877 of June 24, 2019. Fed Reg. 2019; 84(124):30849-52. Available at: https://www.federalregister.gov/documents/2019/06/27/2019-13945/improving-price-and-quality-transparencyin-american-healthcare-to-put-patients-first. Accessed August 5, 2019.

10. Chronic Disease Management Act of 2019. S 1948, 116th Congr (2019). Available at: https://www.congress.gov/bill/116th-congress/senate-bill/1 948 ? $\mathrm{q}=\% 7 \mathrm{~B} \% 22 \mathrm{search} \% 22 \% 3 \mathrm{~A} \% 5 \mathrm{~B} \% 22 \mathrm{~S} .1948 \% 22 \% 5 \mathrm{D} \% 7 \mathrm{D} \& \mathrm{~s}=1 \& \mathrm{r}=1$. Accessed August 5, 2019

11. Chronic Disease Management Act of 2019. HR 3709, 116th Congr (2019). Available at: https://www.congress.gov/bill/116th-congress/housebill/3709? q=\%7B\%22search $\% 22 \% 3 \mathrm{~A} \% 5 \mathrm{~B} \% 22 \mathrm{Hr}++3709 \% 22 \% 5 \mathrm{D} \% 7 \mathrm{D} \& \mathrm{~s}=2$ $\& r=1$. Accessed August 5, 2019.

12. U.S. Department of the Treasury. Treasury expands health savings account benefits for individuals suffering from chronic conditions [press release]. July 17, 2019. Available at: https://home.treasury.gov/news/pressreleases/sm733. Accessed August 5, 2019.

13. Choudhry NK, Bykov, K, Shrank WH, et al. Eliminating medication copayments reduces disparities in cardiovascular care. Health Aff (Millwood). 2014;33(5):863-70. Available at: https://www.healthaffairs org/doi/full/10.1377/hlthaff.2013.0654?url_ver=Z39.88-2003\&rfr_ $\mathrm{id}=$ ori\%3Arid\%3Acrossref.org\&rfr_dat=cr_pub\%3Dpubmed\&. Accessed August 5, 2019

14. Centers for Medicare \& Medicaid Services. Medicare Advantage valuebased insurance design model. Updated May 22, 2019. Available at: https:// innovation.cms.gov/initiatives/V-BID/. Accessed August 5, 2019.

15. Agarwal R, Gupta A, Fendrick AM. Value-based insurance design improves medication adherence without an increase in total health care costs. Health Aff (Millwood). 2018;37(7):1057-64. Available at: https://doi. org/10.1377/hlthaff.2017.1633. Accessed August 5, 2019.

16. Mafi JN, Russell K, Bortz BA, Dachary M, Hazel WA. Fendrick AM Low-cost, high-volume health services contribute the most to unnecessary health spending. Health Aff (Millwood). 2017;36(10):1701-04. Available at: https://www.healthaffairs.org/doi/10.1377/hlthaff.2017.0385. Accessed August 5, 2019.

17. Richardson H, Budros M, Chernew ME, Fendrick AM. V-BID X: creating a value-based insurance design plan for the exchange market. Health Affairs Blog. July 15, 2019. Available at: https://www.healthaffairs.org/do/10.1377/ hblog20190714.437267/full/. Accessed August 5, 2019.

\section{Value-Driven Treatment Decisions: Need of the Hour for Relapsed/Refractory Multiple Myeloma}

In the article "A U.S. Cost Analysis of Triplet Regimens for Patients with Previously Treated Multiple Myeloma," which was published in the April issue of JMCP, ${ }^{1}$ Hollmann et al. estimated the average 1-year cost of treatment for triplet regimens that were approved by the U.S. Food and
Drug Administration and recommended by the National Comprehensive Cancer Network for previously treated multiple myeloma (MM) with the intent to provide a "value-based" assessment. However, the authors failed to consider key elements of value, specifically overall survival (OS) and quality of life (QoL), making their value assessment incomplete. In contrast, the ASCO Value Framework primarily determines 